ENTREPRENEURSHIP AND SUSTAINABILITY ISSUES

ISSN 2345-0282 (online) http://jssidoi.org/jesi/

2019 Volume 7 Number 2 (December)

http://doi.org/10.9770/jesi.2019.7.2(20)

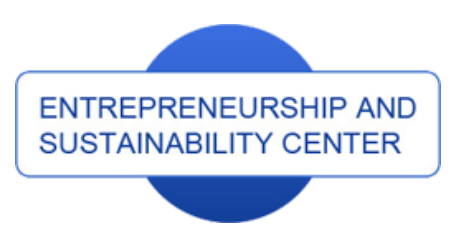

Publisher

http://jssidoi.org/esc/home

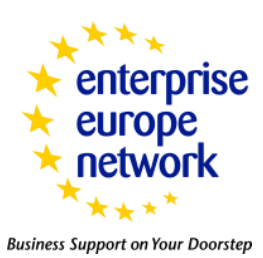

CASPA

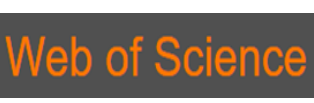

Clarivate
Analytics

\title{
CONTROL IN THE HUMAN CAPITAL MANAGEMENT SYSTEM IN THE STRATEGY OF INNOVATIVE DEVELOPMENT OF A REGION
}

\author{
Vladislav Gerasimov ${ }^{1}$, Rustam Sharafutdinov ${ }^{2}$, Vladimir Kolmakov ${ }^{3}$, Elmira Erzinkyan ${ }^{4}$, \\ Aleksandr Adamenko ${ }^{5}$, Anastasiya Vasilyeva ${ }^{6}$
}

\footnotetext{
${ }^{1}$ Kazan Federal University, Naberezhnye Chelny Institute of KFU, Mira Street, 68/19 (1/18), 423812, Naberezhnye Chelny, Russia

${ }^{2}$ Kazan Federal University, Elabuga Institute of KFU, Kazanskaya Street, 89, 423604, Elabuga, Russia

${ }^{2}$ Academy of Sciences of the Republic of Tatarstan, Center of Advanced Economic Research, Karl Marx Street, 23/6, 420111, Kazan, Russia

${ }^{3}$ Plekhanov Russian University of Economics, Stremyanny lane, 36, 117997, Moscow, Russia

${ }^{4}$ State Academic University for Humanities (GAUGN), Maronovskiy pereulok, 26, 119049, Moscow, Russia

${ }^{5}$ Kuban State Agrarian University named after I.T. Trubilin, Kalinina Street, 13, 350044, Krasnodar, Russia

${ }^{6}$ Nosov Magnitogorsk State Technical University, Lenin Avenue, 38, 455000, Magnitogorsk, Russia
}

\section{E-mail: ${ }^{2}$ rustamsharafutdinov@bk.ru (corresponding author)}

Received 15 March 2019; accepted 25 September 2019; published 15 December 2019

\begin{abstract}
This research paper examines the control function and its importance in the processes of formation and development of human capital to ensure the innovative development of a region using the example of the Republic of Tatarstan. The authors have examined the main control mechanisms in the field of human capital training, as well as in the high-tech and innovative sectors of the economy of the Republic of Tatarstan, and they offer their own recommendations for its improvement. To conduct the study, statistical methods were used to collect and analyze data in order to identify the weaknesses and strengths in the system of monitoring the development of human capital. Based on the study, a model of innovative development of the Republic of Tatarstan, supplemented with control elements, was proposed in terms of providing it with human capital. The practical significance of the results obtained is to supplement the theoretical provisions of the control function in the system of state and regional management in the interests of innovative development.
\end{abstract}

Keywords: human capital management system; human capital of a region; control function; innovative development of a region; the Republic of Tatarstan; innovation development strategy; cluster approach; intellectual and innovative potential of a region

Reference to this paper should be made as follows: Gerasimov, V., Sharafutdinov, R., Kolmakov, V., Erzinkyan, E., Adamenko, A., Vasilyeva, A. 2019. Control in the human capital management system in the strategy of innovative development of a region, Entrepreneurship and Sustainability Issues, 7(2), 1074-1088. http://doi.org/10.9770/jesi.2019.7.2(20)

JEL Classifications: E24, E20, E02, E00. 


\section{ENTREPRENEURSHIP AND SUSTAINABILITY ISSUES}

ISSN 2345-0282 (online) http://jssidoi.org/jesi/

2019 Volume 7 Number 2 (December)

http://doi.org/10.9770/jesi.2019.7.2(20)

\section{Introduction}

Today, the Russian economy is affected by a huge number of global challenges of an internal and external nature related to the decline in industrial production, the growth of social inequality and the deterioration of the general social and economic situation in its regions (Nagimov et al., 2018). In the context of intensified globalisation processes and scientific and technological progress, the Russian economy in order to increase its competitive position in the world market must be primarily high-tech and innovative (Korableva et al., 2018; Mironov et al., 2018a). The matter is that currently in the developed countries of the world the growth of gross regional product thanks to innovative goods and services reaches $85 \%$ of the total gross regional product. This is due to the fact that about $90 \%$ of the entire intellectual and innovative potential of the world is concentrated in these countries, with over $80 \%$ of the high technology market being under their control. Revenue from this market exceeds \$ 2.9 trillion per year and continues to grow, which is well above the extractive and energy sectors (Mironov et al., 2018a). Innovative technologies, as a rule, require a significant amount of investment, including in human capital, both at the state level and at the private entrepreneurial level (Danchikov et al., 2018; Plotnikov et al., 2019; Orynbassarova et al., 2019).

The effective innovative activity of a region largely depends on the proper use of human capital, since institutional development in any economic system is carried out under state control (Lebedeva et al., 2016; Kondrashova et al., 2015). At present, control as a management function is recognized as the determining component of the process in achieving high quality work not only of enterprises, but also of regional systems. Control is an information system, including the collection, processing, storage and transmission of management information (Gurieva et al., 2016). There is generally accepted logic: no control, no exact implementation of the plan, no high result of the enterprise. This statement is also true for a regional economic system (Mironov et al., 2018b; Korableva et al., 2019). Control, as an institution of economic security, allows us to evaluate the fulfillment of the tasks set, the achievement of the stated indicators and is effective only with correctly selected targets that the economic entity seeks to achieve (Akhmetshin \& Vasilev, 2016; Rahim et al., 2017; Korableva et al., 2019). Human capital, like any other component of socio-economic development, requires clear timely monitoring. The main indicators of human capital in the framework of the innovative development of a region include both the indicators shaping it (the availability of higher education, the costs of educational and scientific activities), and the indicators characterizing its effectiveness - the share of innovative goods and services in the total volume of GRP, etc. The main task of managing human capital is the creation of favourable conditions, including motivation and retention of the labour potential of a region and the formation of an innovative type of thinking in all sectors of economics (Latyshev, 2015; Ibatova et al., 2018; Girdzijauskaite et al., 2019; Prodani et al., 2019; Orynbassarova et al., 2019; Bernardi, 2019).

Thus, the key element in the management of human capital to ensure innovation is control, which should be directly related to the general strategic concept of the region development (Brager et al., 2018).

\section{Methodology}

This scientific work was formed based on the following stages of scientific research:

1. The first stage consisted in studying theoretical provisions on control as a management function and showing its relationship with the human capital management system in the interests of the innovative development of regional economic systems.

2. The second stage was dedicated to analysing the economic development of the Republic of Tatarstan and studying the system of management and development of human capital. The innovation system of the region was studied in more detail and the mechanisms for monitoring these systems were examined. The study identified the 


\section{ENTREPRENEURSHIP AND SUSTAINABILITY ISSUES}

ISSN 2345-0282 (online) http://jssidoi.org/jesi/

2019 Volume 7 Number 2 (December)

http://doi.org/10.9770/jesi.2019.7.2(20)

main problems associated with the formation of human capital in the interests of the innovative development of regional economic systems that had arisen due to the insufficient level of implementation of the control function.

3. The third stage presents the author's recommendations for improving the system of human capital formation in the strategy of innovative development.

The theoretical basis of the study was formed by the results of fundamental scientific works of leading domestic and foreign scientists whose research was devoted to the control functions in management, to human capital and human resource management, as well as studies on the relationship of human capital and innovative development (Vorobeva et al., 2016; Singareddy et al., 2019; Trofimova et al., 2019; Voronkova et al., 2019).

The methodological basis of the study is the dialectical method, a systematic approach to the analysis of the facts and phenomena under consideration. The study is based on the wide use of methods of analysis and synthesis, systematisation and complexity, comparative analysis, factor analysis, as well as methods of structural-functional, statistical analysis. The above methods were used in various combinations at different stages of the study, depending on the goals and tasks to be solved, which undoubtedly contributed to ensuring the reliability of the analysis and the validity of the conclusions made by the authors (Osadchy, 2015)

The empirical base used was the database of the Federal Service for Regional Statistics of the Republic of Tatarstan, the results of statistical and sociological studies, legal acts of the Republic of Tatarstan (Innovation Memorandum, Law on Innovation Activities, the Strategy for the Development of Human Capital until 2030), as well as materials from scientific seminars and scientific and practical conferences.

\section{Data, analysis, and results}

\subsection{Problems of innovative development of the Republic of Tatarstan}

The subject of the Russian Federation, the Republic of Tatarstan, was taken as the object under study in this work. The choice of this region is due to the fact that the Republic of Tatarstan is traditionally considered to be the oilproducing region of Russia, that is, depending on the raw material sector of the economy, which is inherent in many regions of the Russian Federation. For this very reason, the development of the innovation sector in the Republic of Tatarstan through the formation of competitive human capital is of great importance, since most of the region's tax revenues come from income tax from the oil and gas sector (Table 1), (Fig. 1).

Table 1: The structure of tax and non-tax revenues of the budget of the Republic of Tatarstan in the years 2014 to 2018 , percentage

\begin{tabular}{|l|r|r|r|r|r|}
\hline \multirow{2}{*}{ Revenue Type } & \multicolumn{5}{|c|}{ Yearly Values } \\
\cline { 2 - 6 } & 2014 & 2015 & 2016 & 2017 & \multicolumn{1}{c|}{2018} \\
\hline Income tax & $47 \%$ & $41 \%$ & $39 \%$ & $37 \%$ & $40 \%$ \\
\hline Personal income tax & $23 \%$ & $26 \%$ & $25 \%$ & $30 \%$ & $27 \%$ \\
\hline Property tax & $13 \%$ & $16 \%$ & $12 \%$ & $14 \%$ & $13 \%$ \\
\hline Excise taxes & $12 \%$ & $14 \%$ & $13 \%$ & $13 \%$ & $12 \%$ \\
\hline Total Income Taxes & $2 \%$ & $2 \%$ & $2 \%$ & $3 \%$ & $3 \%$ \\
\hline Other tax revenues & $2 \%$ & $2 \%$ & $3 \%$ & $1 \%$ & $3 \%$ \\
\hline Non-tax revenues & $2 \%$ & $1 \%$ & $6 \%$ & $2 \%$ & $2 \%$ \\
\hline
\end{tabular}

When considering the structure of income tax (Figure 1), it becomes obvious that almost half of this tax is formed by oil companies. 


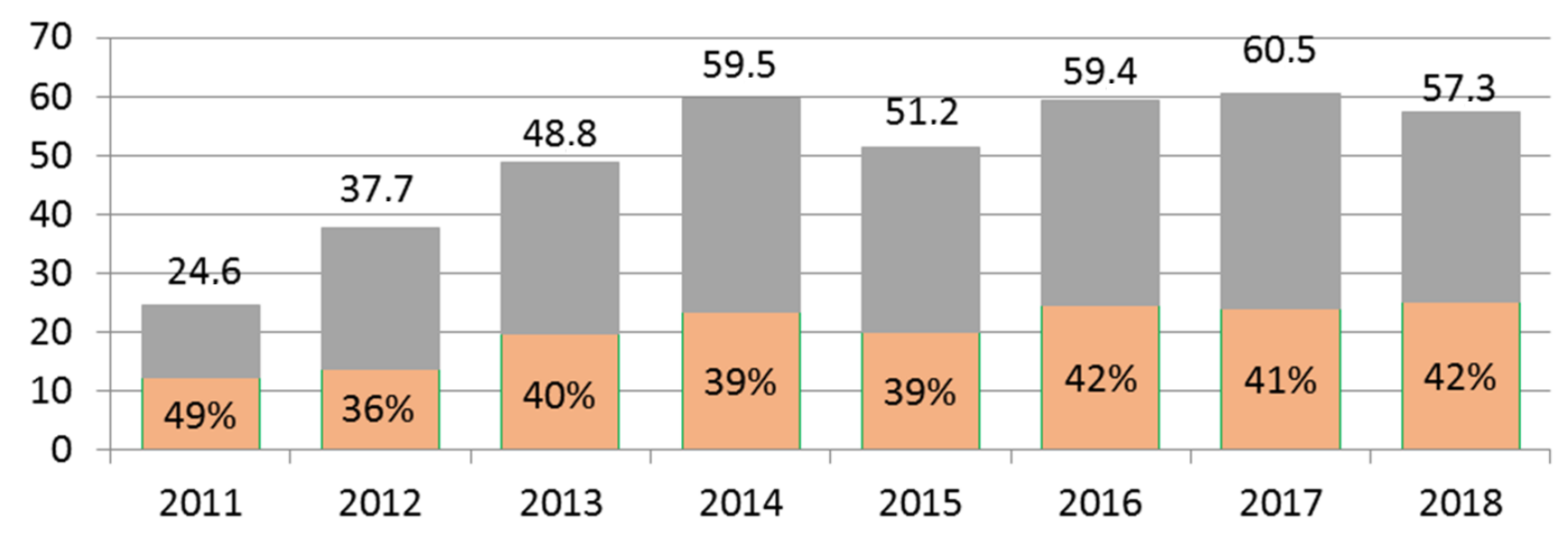

Income tax

Fig.1. The volume of income tax to the budget of the Republic of Tatarstan, billion rubles

In the future, this dependence on the oil sector is going to bear not only economic risks, due to the declining cost of oil on the world market, but also those of environmental safety. Therefore, it is necessary to develop the sector of high-tech, knowledge-intensive and innovative products. As we have noted earlier, in developed countries, gross domestic product growth of more than $70 \%$ falls on innovative products and science-intensive products, which means that it is necessary to invest as much as possible in the development and formation of intellectual and innovative potential (Akhmetshin, 2017).

However, this is possible only with a high level of human capital in the field of scientific and innovative activity. Human capital combines the competencies and skills of people. Their relationship becomes the basic component of intellectual capital; intellectual capital, in turn, together with financial capital make up the common value of companies and regional systems (Gabaidullina et al., 2018). Therefore, it is so important to coordinate the actions of regional mechanisms in the field of human capital formation.

\subsection{The human capital management system of the Republic of Tatarstan in the field of innovation}

For this reason, since 2012, more and more attention has been paid in the Republic of Tatarstan to innovations and human capital showing high potential. Consider human capital and its indicators characterizing the premises of its development and use in the field of innovation (Table 2).

Table 2. Innovative and intellectual potential of human capital of the Republic of Tatarstan

\begin{tabular}{|c|c|c|c|c|c|c|}
\hline \multirow{2}{*}{ Parameter Name } & \multicolumn{6}{|c|}{ Yearly Values } \\
\hline & 2013 & 2014 & 2015 & 2016 & 2017 & 2018 \\
\hline \multicolumn{7}{|c|}{ 1. Intellectual and Innovative Potential } \\
\hline Coverage of the population with higher education programs, $\%$ & 30.3 & 29.9 & 29.2 & 27.5 & 26.5 & 26.4 \\
\hline Of these, due to the budget allocation, $\%$ & 42 & 45 & 46 & 49 & 51 & 52 \\
\hline Average cost of higher education for 1 semester, rubles & 31973 & 34500 & 39502 & 43751 & 48159 & 53350 \\
\hline $\begin{array}{l}\text { Proportion of economically active population with higher education (among } \\
\text { population groups of } 25 \text { to } 64 \text { years old), } \%\end{array}$ & 31.5 & 32.7 & 33.1 & 34.5 & 35.1 & 36.3 \\
\hline Number of graduate students and doctoral students per 100 thousand people & 110.5 & 113.7 & 115.2 & 112.5 & 114.2 & 115.3 \\
\hline $\begin{array}{l}\text { Number of personnel engaged in research and development, per } 10 \text { thousand } \\
\text { people. employed in the economy }\end{array}$ & 72.8 & 75.4 & 72 & 36.3 & 37.6 & 37.8 \\
\hline Number of articles published in peer-reviewed journals indexed at the & 27.2 & 22.8 & 20.3 & 16.9 & 10.5 & 4.3 \\
\hline
\end{tabular}




\section{ENTREPRENEURSHIP AND SUSTAINABILITY ISSUES}

ISSN 2345-0282 (online) http://jssidoi.org/jesi/

2019 Volume 7 Number 2 (December)

http://doi.org/10.9770/jesi.2019.7.2(20)

\begin{tabular}{|c|c|c|c|c|c|c|}
\hline Russian Science Citation Index, per 100 researchers. & & & & & & \\
\hline $\begin{array}{l}\text { Number of patent applications for inventions filed with Rospatent by } \\
\text { national applicants, in relation to the number of economically active } \\
\text { population, per } 10 \text { thousand population }\end{array}$ & 551 & 668 & 550 & 602 & 564 & 592 \\
\hline \multicolumn{7}{|l|}{ 2. Investment in Science and Innovation } \\
\hline $\begin{array}{l}\text { Share of domestic research and development costs in gross regional product, } \\
\text { percent }\end{array}$ & 0.75 & 0.9 & 1.05 & 1.4 & 1.77 & 2.0 \\
\hline $\begin{array}{l}\text { Proportion of the cost of research and development, financed from own } \\
\text { funds of organizations, percent }\end{array}$ & 30.0 & 33.0 & 35.0 & 36.0 & 38.0 & 40.0 \\
\hline Public spending on education, as a percentage of gross regional product & 22.4 & 23.1 & 21.3 & 19.1 & 17.2 & 21.0 \\
\hline $\begin{array}{l}\text { Shares of investments in education, to the total volume of investments in } \\
\text { fixed assets to GRP }\end{array}$ & 1.4 & 2.3 & 2.3 & 1.7 & 2.6 & 1.2 \\
\hline \multicolumn{7}{|c|}{ 3. Intellectual and Innovation Performance } \\
\hline Share of innovative products in gross regional product, percent & 15.6 & 14.9 & 18.4 & 21.1 & 20.5 & 20.4 \\
\hline Share of high-tech and knowledge-intensive industries in GRP,\% & 18.4 & 19.9 & 20.6 & 19.3 & 20.5 & 18.8 \\
\hline
\end{tabular}

According to the above Table 2, the Republic of Tatarstan has a huge reserve of human capital, especially in the field of innovation. However, in recent years there has been a noticeable decrease in innovation processes, since there has been an almost twofold reduction in the number of scientists, with no change in the number of doctoral school graduates. In addition, the level of accessibility of higher education is declining more and more due to a significant increase in the prices of higher education programs (Tarman, 2016; Tarman and Chigisheva, 2017). There is a drop in inventive activity of the population. At present, the accumulated human capital allows maintaining a high level of innovative activity in the region, however, continuing negative trends may cause a number of problems in the future, which indicates an insufficient degree of control over the processes of human capital formation and development in the interests of innovative progress.

Consider the management system of human capital. As it is, the human capital management system of the Republic of Tatarstan is a set of interconnected systems, programs and management methods involved in the development, formation and use of human capital at the federal, regional and municipal levels. The parts of the human capital management system in the Republic of Tatarstan considered as the most important are as follows (Figure 2):

- Ministry of Education and Science;

- Ministry of Labour, Employment and Social Protection;

- Ministry of Youth and Sports;

- Ministry of Culture;

- Ministry of Economics;

- Ministry of Health.

These ministries, within their competences, participate in the formation, accumulation and use of human capital of the Republic of Tatarstan. In addition to ministries, there are many commissions and councils. One of them is the Interdepartmental Commission for the implementation of the state personnel policy in the sectors of the economy of the Republic of Tatarstan. The next body is the Government Commission of the Republic of Tatarstan on science, technology and innovation policy. It is also worth noting that in 2014 the Council on Personnel Policy under the President of the Republic of Tatarstan was created in order to effectively use the personnel potential, promote the development of the system of state civil and municipal service in the Republic of Tatarstan, and implement a comprehensive personnel policy. In order to develop human capital as a driving force of the economy, a strategy for the development of human capital was launched in the Republic of Tatarstan in 2014 - the 
Republic of Tatarstan Strategy 2030. In this strategy, a special role is given to the development of the institutional grounds for the formation and development of competitive human capital (Fig. 2).

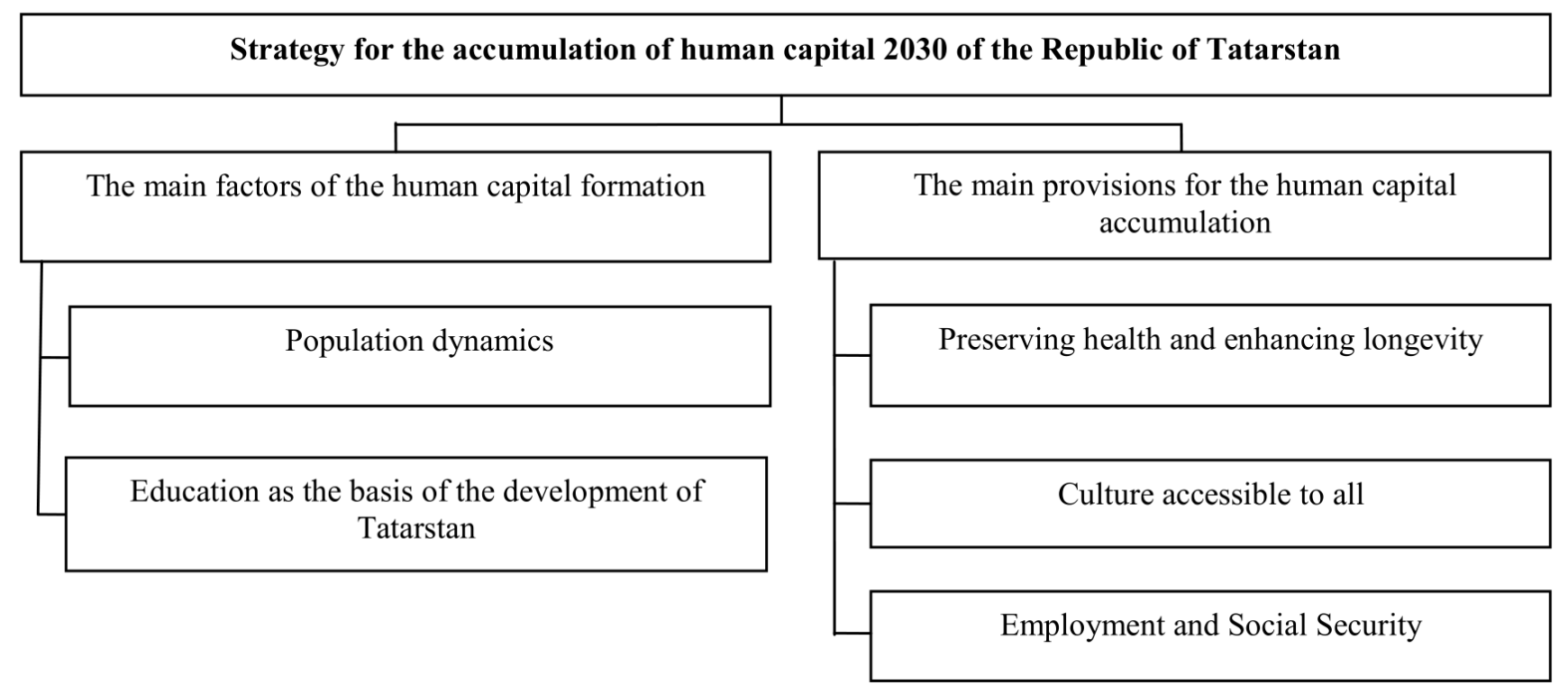

Fig. 2. Human Capital Development Program of the Republic of Tatarstan

Thus, the formation of the unified strategy of the Republic of Tatarstan 2030 is an attempt to combine innovations and the human capital management system. However, due to poor preparation and problems in the regional economic system, this program is not being fully implemented and the program phasing regulations are not followed.

Regarding the innovation system of the Republic of Tatarstan, the innovative potential of the region is determined by the presence of a number of premises for the formation and implementation of innovative activities, namely the existence of a developed intellectual and innovative infrastructure in the form of research and development institutions, appropriately trained personnel, and a developed personnel training system capable of active interaction with industrial and other sectors of the economy (Vasilev et al., 2017; Erokhina, 2013). Today, the Republic of Tatarstan has created almost all types of infrastructure for economic and scientific activities: a special economic zone, a technopolis, industrial parks, science parks, business incubator zones, Innopolis. Residents of the above subjects of innovation infrastructure are mainly representatives of foreign small and medium enterprises (Krotkova, 2016). In addition, clustering is particularly well developed. The experience of applying the cluster approach in Western countries shows that, clustering as an economic model is more effectively applicable in the issues of innovative interaction of regional economic systems (Kolpak et al., 2017; Chernetsov, 2015). In addition, economic clusters act as an important tool in modern state innovation policy (Tsertseil, 2017; Nahm, 2011; Mazur et al., 2017; Neizvestnaya et al., 2018; Kolmakov et al., 2019). They were conceived as tools that could combine many areas of economic activity that are separate elements of the region's innovation system (science, business, education, etc.) and ensure their structural updating (Barmuta et al., 2017). These structures were created as part of the innovative strategy of the Republic of Tatarstan, the provisions of which, in the form of an organizational structure, are also taken into account in Strategy 2030.

In the framework of the 2030 program of the Republic of Tatarstan, the following innovative structure of the region is planned (Fig. 3). 


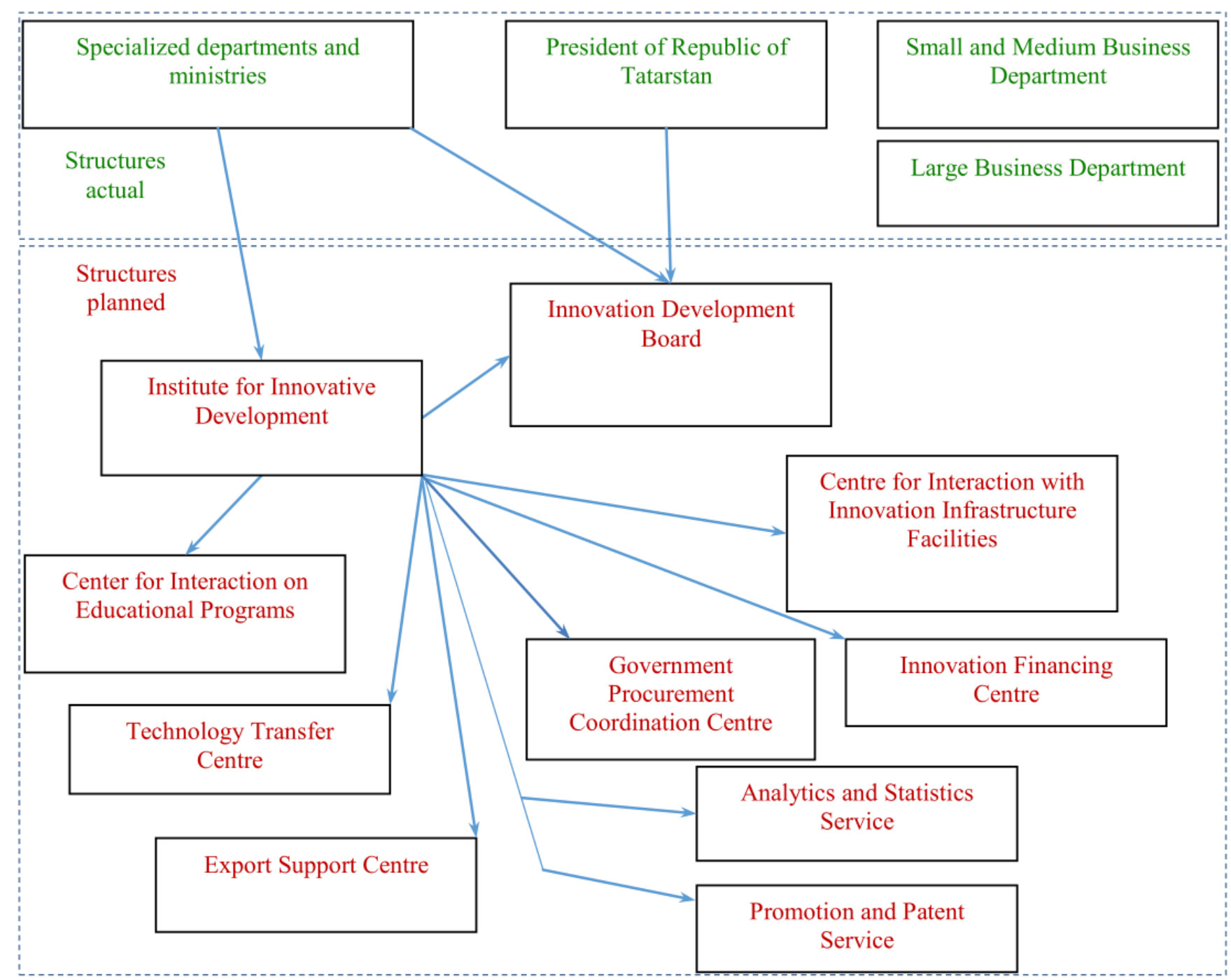

Fig.3. Structures of the system of innovative development of the Republic of Tatarstan

* already created structures are marked in green, planned ones in red.

In this innovative structure, according to the authors, number of units are absent that are important in the framework of innovative development, and there are no units that would be responsible for monitoring the implementation of development targets. Also, there is almost no system of reporting and accountability, and that of control of some structures. 


\subsection{Proposed Measures to Implement the Control Function in the Human Capital Management System in the Strategy of Innovative Development of the Republic of Tatarstan}
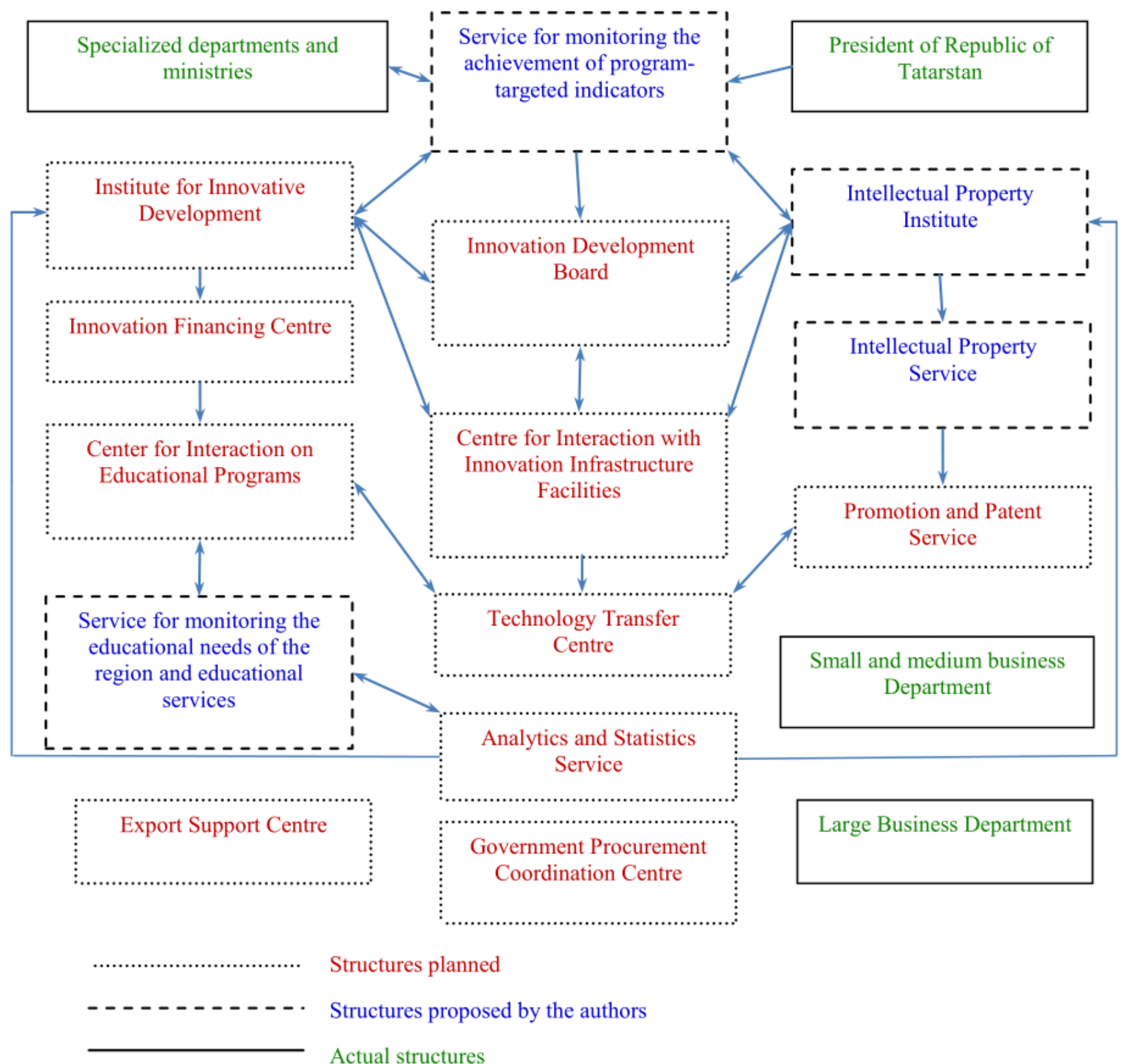

Fig.4. The proposed augmented scheme of the innovative structure of the Republic of Tatarstan

* already existing structures are marked in green, planned ones - in red, those proposed by the authors - in blue. 


\section{ENTREPRENEURSHIP AND SUSTAINABILITY ISSUES}

ISSN 2345-0282 (online) http://jssidoi.org/jesi/

2019 Volume 7 Number 2 (December)

http://doi.org/10.9770/jesi.2019.7.2(20)

Within the framework of the structure offered, it is proposed to introduce several monitoring services, namely:

1) A service for monitoring the achievement of program-targeted indicators, which is to monitor the overall effectiveness of the human capital development strategy in general, and within the framework of innovative development. This service should identify the reasons for not achieving the goals and objectives set, as well as present for public review the annual results of the effectiveness of innovation in all programs.

2) Creation of the Intellectual Property Institute. This will significantly increase the inventive activity of citizens, as the intellectual property market will be formed, and the process of patenting the results of intellectual activity, their publication, application and protection will be supported by the intellectual property service.

3) Service for monitoring the educational needs of the region and educational services. This service will be responsible for the annual adjustment of the region's needs for highly qualified human capital, it will also monitor and regulate the price level for educational services of regional institutions, in line with the current socioeconomic situation.

\section{Discussion}

Based on the data obtained during the study, we can draw the following conclusions:

1) In the future, the economic growth of developed countries will be ensured by scientific and technological progress and the intellectualisation of the main components of the means of production in all areas of the economy. Russia should enter the new stage of development and be among the leading countries in scientific, technical and innovative development (Rahman and Bobkova, 2017; Yemelyanov et al., 2019). To ensure sustainable economic growth in the country in the long run, it is necessary to make the transition to an innovative type of development and to get rid of raw material dependence. This scenario is only possible with efficient mechanisms for the human capital formation and development in innovative sectors of the economy not only in regions, but also in the private sector as a whole. The effectiveness of the innovation management system in this case is largely determined by the control subsystem that meets the adequate, timely goals and objectives of the regional development management (Vasilev et al., 2017).

2) One of the main values of the socio-economic development of the regions is control over the volume of investments in human capital in the interests of innovative development (Qu et al., 2017). The choice of an investment object cannot be spontaneous and must be justified, since choice is a complex process of careful selection, evaluation and analysis of various options. Then comes the final choice of the object (Artemova et al., 2017).

3) Control over fulfilment of objectives is meant to assess the need to change the strategy based on the results of the intermediate stages of the implementation of strategies. Tasks to be monitored usually fall into one of two types: regional results achieved in the intermediate stages of the overall long-term strategy, and strategic project results (Gabidinova, 2016).

4) Quantitative and qualitative indicators traditionally used in management, methods of ignoring non-financial indicators, such as product quality and customer satisfaction, staff quality and training, product innovation, flexibility and adaptability of production and management systems and technologies, lead to optimisation of the company's activities in the short term. However, in parallel, this leads to a contradiction of the results of managerial control to the development strategy of the company, the disregard of the influence of the external 


\section{ENTREPRENEURSHIP AND SUSTAINABILITY ISSUES}

ISSN 2345-0282 (online) http://jssidoi.org/jesi/

2019 Volume 7 Number 2 (December)

http://doi.org/10.9770/jesi.2019.7.2(20)

environment and the activities of competitors, which is also natural for regional economic systems (Mullakhmetov \& Sadriev, 2018; Schäfer. 2001; Vasilev et al., 2018).

5) The current human capital management system in the interests of the innovative development of the Republic of Tatarstan has a number of shortcomings related to the organisational structure, in particular, the lack of control groups in various fields responsible for both the formation of human capital and the development of mechanisms for activating labour in the field of innovative activity (Abilova, 2010; Dudin, 2017). The program for the human capital development of the Republic of Tatarstan 2030, does not give a comprehensive picture of the target indicators for the development of human capital and a number of other, no less important indicators, including the linking of performers and accountability in the executing structures. The introduction of mechanisms to control pricing in personnel training and intellectual property services on the part of the regional system will significantly improve the accessibility of higher education, and therefore indirectly affect the growth of innovative and inventive activity.

\section{Conclusion}

In conclusion, it is worth noting that in the context of the region's innovative development, the human factor, namely human capital, becomes the main driving force behind innovation processes and activities. It is this indicator that determines the effectiveness and formation of socio-economic programs for the development of regions and the activities of authorities using powerful institutional control systems (Morozov et al., 2018; Stoyanovskaya, 2014).

The study has shown that when organizing the management of regional systems, it is the control function that is one of the most important elements of management not only in the private sector, but also in the public sector, as it is responsible for achieving the goals and objectives set for the region (Mullakhmetov \& Nazmiev, 2015). This is especially relevant and important in the field of human capital management in the strategy of innovative development, which requires a high level of development and rapid adaptation to constantly changing modern conditions.

It was found that the Republic of Tatarstan has a strong human potential in the field of innovation, developing under the Strategy of the Republic of Tatarstan 2030, however, in this system there are not enough control bodies and a number of other structures, which is going to negate in some time all the results achieved, as the accessibility of higher education of the population tends to significantly decrease, the inventive activity of the region is becoming less intensive due to the lack of an intellectual property institution, and a number of other reasons. In view of this, we propose our own innovative structure of human capital development, with additional control elements.

The proposed organisational control structures in the innovation system of the Republic of Tatarstan can help in the human capital formation to ensure the strategy of innovative development and create favourable conditions for pursuing innovative and investment economic policies of the region.

Thus, it is necessary to continue the active development and modernization of the existing programs for the human capital development. Tatarstan needs emphasis on the preparation of innovative programs for territorial clusters, priority development areas and special economic zones, the creation and development of which is laid down in the strategic development program of Tatarstan until 2030, using the main factor - human capital. It is necessary to develop strategic programs for the development and support of domestic business in the framework of import substitution, attracting local small and medium-sized businesses, providing them with financial and informational support. The development of joint activities of regional universities and national companies will 


\section{ENTREPRENEURSHIP AND SUSTAINABILITY ISSUES}

ISSN 2345-0282 (online) http://jssidoi.org/jesi/

2019 Volume 7 Number 2 (December)

http://doi.org/10.9770/jesi.2019.7.2(20)

increase the quantity and quality of high-tech products that can meet current and future global challenges. However, all this is only possible with a balance of regional human resource needs and their potential values in various sectors of the economy (Abilova, 2010). Therefore, this topic requires further in-depth research and individual studies, especially in the staff training system, human capital management and its control system.

\section{References}

Abilova, M. G. (2010). Revitalization of reproductive labour in Russia: methods for assessing the efficiency of the process and their implementation. Bulletin of Magnitogorsk State Technical University named after G.I. Nosov, 3(31): 64-66.

Akhmetshin, E. M. (2017). The System of Internal Control as a Factor in the Integration of the Strategic and Innovation Dimensions of a Company's Development. Journal of Advanced Research in Law and Economics, 8(6): 1684-1692. https://doi.org/10.14505/jarle.v8.6(28).03

Akhmetshin, E. M., \& Vasilev, V. L. (2016). Control as an instrument of management and institution of economic security. Academy of Strategic Management Journal, 15(SpecialIssue1): 1-7.

Artemova, E. I., Vermennikova, L. V., Shichiyakh, R. A., Prodanova, N. A., \& Kuchukova, N. M. (2017). Management of investment attractiveness of enterprises: Principles, methods, organization. International Journal of Applied Business and Economic Research, 15(23): 71-82.

Barmuta, K. A., Yakovenko, Z. M., Zadorozhnaya, L. I., Mironov, D. S., \& Klochko, E. N. (2017). Advantages of cluster approach in managing the economy of the Russian federation. International Journal of Applied Business and Economic Research, 15(23): 355-364.

Brager, D. K., Pokramovich, O. V., Andreyko, M. N., \& Aleynikova, M. Yu. (2018). Modern theoretical and methodological approaches to personnel management in manufacturing enterprises. Espacios, 39(31)

Bernardi, A. (2019). The capability approach and organizational climate as tools to study occupational health and safety. Insights into Regional Development, 1(2), 155-169. https://doi.org/10.9770/ird.2019.1.2(6)

Chernetsov, V. I., Gamidullaev, L. A., Purtova, A. A. (2015). Cluster formation algorithm: the case of the Penza region agricultural sector. Paper presented at the Proceedings of the All-Russian Scientific and Practical Conference Innovation-based Socio-economic development of regions, 232-240.

Danchikov, E., Polyanskaya, T., Plaskova, N., Prodanova, N., \& Zhiltsov, S. (2018). Analysis of innovation activity of enterprises in modern business environment. Journal of Advanced Research in Law and Economics, 8(8): 2311-2323. https://doi.org/10.14505/jarle.v8.8(30).01

Dudin, M. N., Lyasnikov, N. V., Makarov, O. N., Maslennikova, O. A., \& Grebennikov, V. V. (2017). The fostering of motivation for innovative activity in future agriculture specialists as a pedagogical issue. Espacios, 38(40)

Erokhina, E. V. (2013). Regional innovation system and the new management paradigm. Kaluga: ZAO Prait-K.

Gabaidullina, L. A. (2018). Influence of Human Capital Characteristics on Transformation of Management and Control in the Management of Social and Economic Systems. Paper presented at the Proceedings of the 31st International Business Information Management Association Conference - Innovation Management and Education Excellence through Vision 2020, 3562-3572.

Gabidinova, G. S. (2016). Control in marketing-based management. Academy of Marketing Studies Journal, 20(Specialissue2), $13-19$.

Girdzijauskaite, E., Radzeviciene, A., Jakubavicius, A. 2019. Impact of international branch campus KPIs on the university competitiveness: FARE method. Insights into Regional Development, 1(2), 171-180. https://doi.org/10.9770/ird.2019.1.2(7) 


\section{ENTREPRENEURSHIP AND SUSTAINABILITY ISSUES}

ISSN 2345-0282 (online) http://jssidoi.org/jesi/ 2019 Volume 7 Number 2 (December)

http://doi.org/10.9770/jesi.2019.7.2(20)

Gurieva, L. K., Savicheva, A. N., Kataeva(Sventa Yarvik), V. I., \& Norkina, A. N. (2016). Theoretical foundations of management of the organization: Development, types of structures, management methods of control. International Business Management, 10(22): 5406-5416. https://doi.org/10.3923/ibm.2016.5406.5416

Ibatova, A. Z., Nezhmetdinova, F. T., \& Sitdikov, F. F. (2018). Global challenges for the agrarian sector of Russian economy and its human resources. Espacios, 39(26)

Kolmakov, V. V., Polyakova, A. G., Karpova, S. V., \& Golovina, A. N. (2019). Cluster development based on competitive specialization of regions. Economy of Region, 15(1): 270-284. https://doi.org/10.17059/2019-1-21

Kolpak, E. P., Sulimova, E. A., Kireev, V. S., Samarina, E. A., \& Solodilova, N. Z. (2017). Clustering as a criterion for the success of modern industrial enterprises. International Journal of Applied Business and Economic Research, 15(23): 221-231.

Kondrashova, E. A., Veretennikova, I. I., Taburchak, A. P., Ospishchev, P. I., \& Leonova, O. V. (2015). Innovative development of companies as a basis of innovation systems of Russia. Biosciences Biotechnology Research Asia, 12(1): 789-799. https://doi.org/10.13005/bbra/1724

Korableva, O. N., Kalimullina, O. V., Zaytseva, A. A., \& Larionov, A. I. (2018). Elaboration of database for the subject domain of innovation and economic growth potential. Paper presented at the Proceedings of the 31st International Business Information Management Association Conference, IBIMA 2018: Innovation Management and Education Excellence through Vision 2020, 6065-6073.

Korableva, O., Durand, T., Kalimullina, O., \& Stepanova, I. (2019). Studying user satisfaction with the MOOC platform interfaces using the example of coursera and open education platforms. Paper presented at the ACM International Conference Proceeding Series, 26-30. https://doi.org/10.1145/3322134.3322139

Korableva, O.N., Kalimullina, O.V., Mityakova, V.N. (2019) Designing a System for Integration of Macroeconomic and Statistical Data Based on Ontology. Advances in Intelligent Systems and Computing, 998, p. 157-165.

Krotkova, E. V. (2016). State control over small business development: Approaches to the organization and problems (experience of the republic of tatarstan, the russian federation). Academy of Strategic Management Journal, 15(SpecialIssue1): 8-14.

Latyshev, I. O. (2015). Methodological approaches to analyzing the indicators of human capital management in the interests of innovation development of enterprise. International Business Management, 9(6): 1565-1570. https://doi.org/10.3923/ibm.2015.1565.1570

Lebedeva, T. E., Dzagoyeva, M. R., Kobersy, I. S., \& Ikoev, S. K. (2016). Corporate governance issues and control in conditions of unstable capital risk. International Journal of Economics and Financial Issues, 6(1S): 25-32.

Mazur, V. V., Barmuta, K. A., Demin, S. S., Tikhomirov, E. A., \& Bykovskiy, M. A. (2016). Innovation clusters: Advantages and disadvantages. International Journal of Economics and Financial Issues, 6(1S): 270-274.

Mironov, D. S., Yumashev, A. V., Puryaev, A. S., \& Lvov, V. V. (2018a). Innovation process and control function in management. European Research Studies Journal, 21(1): 663-674.

Mironov, D. S., Zatsarinnaya, E. I., Romanova, M. V., \& Yumashev, A. V. (2018b). Internal control system in enterprise management: Analysis and interaction matrices. European Research Studies Journal, 21(2): 728-740.

Morozov, I., Pavlyuk, A., Yumashev, A., Yumasheva, N., \& Gubarkov, S. (2018). Motivation of personnel in an innovative business climate. European Research Studies Journal, 21(1): 352-361.

Mullakhmetov, K. S. \& Sadriev, R. D. (2018). Corporate culture in management systems. European Research Studies Journal, 21(1): 519528.

Mullakhmetov, K. S., \& Nazmiev, E. F. (2015). Control in the system of public administration in Russia. International Business Management, 9(7): 1732-1736. https://doi.org/10.3923/ibm.2015.1732.1736

Nagimov, A. R., Slanov, V. P., Shpakova, R. N., Solomonov, M. P., \& Il'yaschenko, D. P. (2018). Foresight technologies in the formation of a sustainable regional development strategy. European Research Studies Journal, 21(2): 741-752.

Nahm, K. (2011). Regional innovation policy in South Korea: Building science and technology based entrepreneurial development capabilities. Science and technology based regional entrepreneurship: Global experience in policy and program development (pp. 160-183). 


\section{ENTREPRENEURSHIP AND SUSTAINABILITY ISSUES}

ISSN 2345-0282 (online) http://jssidoi.org/jesi/

2019 Volume 7 Number 2 (December)

http://doi.org/10.9770/jesi.2019.7.2(20)

Neizvestnaya D.V., Kozlova N.N., N.A. Prodanova (2018) Application of CVP-Analysis at the Water Transport Organizations. Helix, 8(1), 2811-2815. https://doi.org/10.29042/2018-2811-2815

Orynbassarova, Y., Abzalbek, E., Pritvorova, T., Petrenko, Y. 2019. Regional and product profile of post-industrial services in the economy of Kazakhstan. Insights into Regional Development, 1(4), 343-355. https://doi.org/10.9770/ird.2019.1.4(5)

Osadchy, E. A. (2015). The intellectual capital importance and the role of organizations against the backdrop of a crisis: Innovation vector. Social Sciences (Pakistan), 10(6): 1013-1020. https://doi.org/10.3923/sscience.2015.1013.1020

Plotnikov, A. V., Kovalenko, K. E., Prodanova, N. A., Noeva, E. E., Astapenko, E. O., \& Novikova, Y. A. (2019b). Social entrepreneurship of persons with disabilities. Journal of Entrepreneurship Education, 22(Special Issue 2): 1-9.

Plotnikov, A., Salamzadeh, Y., Demiryurek, K., Kawamorita, H., \& Urasova, A. (2019a). Features of entrepreneurial activities indice in the world: Trends and prospects. International Journal of Entrepreneurship, 23(1).

Prodani, R., Bushati, J., Andersons, A. 2019. An assessment of impact of information and communication technology in enterprizes of Korça region. Insights into Regional Development, 1(4), 333-342. https://doi.org/10.9770/ird.2019.1.4(4)

Qu, Y., Qu, T., \& Wu, Y. (2017). The role of regional formal institutions and foreign direct investment in innovation in Chinese enterprises. Asia Pacific Business Review, 23(1): 27-43. https://doi.org/10.1080/13602381.2015.1094293

Rahim, S. A. A., Nawawi, A., \& Salin, A. S. A. P. (2017). Internal control weaknesses in a cooperative body: Malaysian experience. International Journal of Management Practice, 10(2): 131-151. https://doi.org/10.1504/IJMP.2017.083082

Rahman, P.A., \& Bobkova, E.Yu. (2017). The reliability model of the fault-tolerant border routing with two Internet services providers in the enterprise computer network. Paper presented at the Journal of Physics: Conference Series, 803(1) https://doi.org/10.1088/1742$6596 / 803 / 1 / 012124$

Schäfer, M. (2001). Balanced scorecards - control of strategic planning and management. [Balanced scorecards - Wie man werthebel richtig einstellt] Nachrichten Aus Der Chemie, 49(5): 663-665.

Singareddy, R. R. R., Ranjan, P., Balamurugan, A., \& Shabana, C. (2019). Financial inclusion remodeling: Including the excluded masses. Space and Culture, India, 6(5), 178-188. https://doi.org/10.20896/SACI.V6I5.375

Stoyanovskaya, I. B. (2014). Management of staff motivation at various stages of company development (dissertation for the degree of candidate of economic sciences). Lomonosov Moscow State University, Moscow, Russia.

Tarman, B. (2016). Innovation and Education. Research in Social Sciences and Technology, 1(1). Retrieved from http://ressat.org/index.php/ressat/article/view/3

Tarman, B., \& Chigisheva, O. (2017). Transformation of educational policy, theory and practice in post-soviet social studies education. Journal of Social Studies Education Research, 8(2), I-IV. https://doi.org/0.17499/jsser.93128

Trofimova, L., Prodanova, N., Korshunova, L., Savina, N., Ulianova, N., Karpova, T., \& Shilova, L. (2019). Public sector entities' reporting and accounting information system. Journal of Advanced Research in Dynamical and Control Systems, 11(8 Special Issue), 416424.

Tsertseil, J. S., Kookueva, V. V., Gryzunova, N. V., \& Khashchuluun, C. (2017). Analysis and prospects of infrastructure development of innovation regional clusters in Russia through the example of specific economic zones of industrial production and technology innovation types. Journal of Applied Economic Sciences, 12(7): 1896-1905.

Vasilev, B. U., Grigorev, P. S., \& Shulgenko, V. M. (2018). Configuration and energy supply of promising types of underwater pumping complexes for transportation of hydrocarbons from the shelf. Neftyanoe Khozyaystvo - Oil Industry, (3), 77-81. http://doi:10.24887/0028$\underline{2448-2018-3-77-81}$

Vasilev, V. L., Bakhvalov, S. I., Prikhod'ko, A. N., \& Kazakov, A. V. (2017). Internal control in the system of innovation management in the modern business environment. International Journal of Economic Research, 14(15): 409-416. 


\section{ENTREPRENEURSHIP AND SUSTAINABILITY ISSUES}

ISSN 2345-0282 (online) http://jssidoi.org/jesi/

2019 Volume 7 Number 2 (December)

http://doi.org/10.9770/jesi.2019.7.2(20)

Vorobeva, N. A., Beletskaya, S. A., \& Kolesnikov, M. V. (2016). Innovation development of Russia and participation in the integration process of the Asia-pacific region. International Journal of Economics and Financial Issues, 6(3): 1038-1048.

Voronkova, O. Y., Iakimova, L. A., Frolova, I. I., Shafranskaya, C. I., Kamolov, S. G., \& Prodanova, N. A. (2019). Sustainable development of territories based on the integrated use of industry, resource and environmental potential. International Journal of Economics and Business Administration, 7(2), 151-163.

Yemelyanov, V. A., Fatkulin, A. R., Nedelkin, A. A., Titov, V. A., \& Degtyarev, A. V. (2019). Software for weight estimation of the transported liquid iron. Paper presented at the Proceedings of the 2019 IEEE Conference of Russian Young Researchers in Electrical and Electronic Engineering, ElConRus, 381-384. https://doi.org/10.1109/EIConRus.2019.8657011

Vladislav Olegovych GERASIMOV, Postgraduate student, Department of Economics of Enterprises and Organizations, Naberezhnye Chelny Institute of Kazan Federal University. Currently engaged to offer human capital an estimation methodological approach in the Republic of Tatarstan and the Volga Federal District regions. Evaluation is carried out with innovation and intellectual capital, taking into account the human capital forecast development and its recommendations for Tatarstan. Research interests: human capital of the Republic of Tatarstan, the innovative potential of the region, the intellectual potential of the region, the labor potential of the region, the composite index of human capital, the aggregate intellectual and innovative potential.

ORCID ID: orcid.org/0000-0002-5432-054X

Rustam Ilfarovich SHARAFUTDINOV, Postgraduate student of the Center for Advanced Economic Research of the Academy of Sciences of the Republic of Tatarstan. His research interests are in economics and management, socio-economic development and inclusive growth. Research interests: human capital; inclusive growth and development; sustainable development; innovative development; social and economic development.

ORCID ID: orcid.org/0000-0001-9493-9366

Vladimir Vladimirovich KOLMAKOV, PhD in Economics, Associate Professor of Economics, University Lecturer and Director of the BA in Financial Management at the Faculty of Finance, Plekhanov Russian University of Economics. Research interests: regional studies and regional development, corporate finance.

ORCID ID: orcid.org/0000-0002-2801-4290

Elmira Arsenovna ERZINKYAN, Associated professor, Institute of economics, State Academic University of Humanities. Currently engaged in teaching economics and management disciplines at the Institue of Economics, State Academic University of Humanities and research in the field of management, economic theory, entrepreneurship. Research interests: financial management, investment analysis, history of economic thought.

ORCID ID: orcid.org/0000-0003-2942-3288 


\section{ENTREPRENEURSHIP AND SUSTAINABILITY ISSUES}

ISSN 2345-0282 (online) http://jssidoi.org/jesi/

2019 Volume 7 Number 2 (December)

http://doi.org/10.9770/jesi.2019.7.2(20)

Alexander Alexandrovich ADAMENKO, Doctor of Economics, Professor of the Department of Accounting Theory of Kuban State Agrarian University named after I.T. Trubilin. It is accredited and included in the Federal Register of Experts in Science and Technology. Research interests: regional economy, innovative development of the region, regional system of entrepreneurship, development of small and medium-sized enterprises.

ORCID ID: orcid.org/0000-0002-7253-0671

Anastasiya Grigoryevna VASILYEVA, PhD in Economics, Associate Professor, Department of Economics and Finance, Institute of Economics and Management, Nosov Magnitogorsk State Technical University. Research interests: sustainable development of territories, resource support of social and economic development of territories.

ORCID ID: orcid.org/0000-0003-0259-1556

Register for an ORCID ID:

https://orcid.org/register

Copyright (C) 2019 by author(s) and VsI Entrepreneurship and Sustainability Center

This work is licensed under the Creative Commons Attribution International License (CC BY).

http://creativecommons.org/licenses/by/4.0/

(c) (i) Open Access 